\title{
A Green Information Technology Governance model for large Mauritian companies
}

\begin{abstract}
Green Information Technology (IT) has emerged as a vital IT governance concern to promote environmentally-friendly IT use and ecologically responsible business processes. Organisational adoption of Green IT is growing in strategic importance, but remains a concern in developing countries, particularly Small Island Developing States (SIDS) such as Mauritius. Despite a strong economic dependence on IT and growing challenges resulting from their environmental vulnerability, the governance of IT and Green IT in SIDS such as Mauritius remains uncharted in existing literature. This study examines IT Governance (ITG) and Green IT in Mauritius by exploring the ITG and Green IT accountabilities, practices and drivers of large Mauritian businesses pertaining to the prime pillars of the Mauritian economy. 109 companies from the population of 192 responded, leading to a response rate of $56.8 \%$. Findings resulting from the exploratory and confirmatory factor analysis of responses were used to develop an IT Governance and Green IT model (ITGM) representing ITG and Green IT accountabilities, mechanisms and drivers among the businesses studied. It is envisaged that the ITGM and its resulting recommendations will provide both Mauritian and other SIDS' companies with a baseline for IT Governance and Green IT practice for improved business IT strategic value.
\end{abstract}

Keywords:

IT Governance, Green IT, IT Governance mechanisms, Green IT mechanisms, Mauritius

\section{Introduction}

Representing a 4.5\% growth from 2017, Gartner (2018) predicts a global \$3.7 trillion of IT expenditure in 2018. Such an escalation in IT investment is fuelled by spiralling business IT reliance, and has triggered a shift from the traditionally reactive function of business IT to a more strategic role for optimal value (Coltman et al., 2015). Conversely, the resulting boost in energy consumption, $\mathrm{CO}_{2}$ emissions and e-waste is strong cause for worry (Murugesan, 2008). If not contained, IT's contribution to global carbon emissions is projected to increase from $2 \%$ (Gartner, 2007) to as much as 6\% in 2020 (Fujitsu, 2010). More than ever, businesses are required to govern environmentally clean IT use (Jairak et al., 2015), and Green IT as an IT Governance decision is crucial in the adoption of IT for environmentally sustainable business processes (Bohas and Poussing, 2016).

The governance of energy-efficient and ecological IT use is particularly important for ITdependent Small Island Developing States (SIDS). Characterised by their small size and vulnerability to economic turbulences and environmental issues, fifty-seven SIDS continuously fight these challenges for their sustainable development (United Nations Sustainable Development Knowledge Platform, 2017). Mauritius is one such example. Good governance, IT excellence and environmental sustainability rank high in the island's 2030 vision (Sourcemauritius.com, 2015). The Mauritian government strongly promotes IT as a key to its development goals ("Budget Speech 2017-2018," 2017), and aspires to turn Mauritius into a sustainable island (Ministry of Environment and Sustainable Development, 2013). Nonetheless, despite its high IT reliance and environmental vulnerability, akin to other SIDS, IT Governance and Green IT in Mauritius remain largely unexplored.

This study examines IT Governance and Green IT measures implemented in Mauritian businesses to formulate an IT Governance and Green IT model (ITGM). It is envisioned that 
the ITGM will assist Mauritian companies, and subsequently similar SIDS, in maximising both their IT business value and sustainability quotient. The remaining sections of this paper are structured as follows. Section 2 presents a review of existing IT Governance and Green IT literature. The section also justifies the rationale for IT Governance and Green IT research in the Mauritian context. Section 3 describes the conceptual IT Governance and Green IT model underlying the study. Section 4 details the research design. This is followed by section 5 which discusses the ITGM findings and provides further recommendations. Section 6 concludes the paper.

\section{Theoretical Background}

\subsection{IT Governance and Green IT}

Coined in the late 1990s, the term IT Governance stems from earlier research on business/IT impact, alignment and investment (De Haes et al., 2013). Since then, effective IT Governance has transcenced IT decision accountabilities alone to also include a set of mechanisms that enhance business/IT synergy for the achievement of business goals (Weill, 2004). Increasingly, ITG underlies corporate governance considerations essential for IT to align with business exigencies (Rubino and Vitolla, 2014) such as growing stakeholder pressure for environmental sustainability (den Uyl and Driessen, 2015). Green IT considerations emanating from top level management (Akman and Mishra, 2015) and rooted in IT governance practices are thus essential for organisations to benefit from the power of IT to enhance clean production.

Several definitions of Green IT have emerged in literature with most of them considering IT environmental sustainability across the IT lifecycle. For example, Molla, Cooper and Pittayachawan (2011, p. 73) define Green IT as the "systematic application of ecologicalsustainability criteria (such as pollution prevention, product stewardship, use of clean technologies) to the creation, sourcing, use and disposal of the IT technical infrastructure as well as within the IT human and managerial practices." This definition also reinforces the importance of Green IT decisions in the governance of IT (ITGI, 2011), as it encompasses human and managerial practices which include Green IT beliefs, strategies and policies essential for the governance of environmentally sustainable IT.

Given the growing strategic importance of Green IT (Akman and Mishra, 2015), the past two decades have seen increasing research on both IT's own carbon footprint and its power to support ecological business processes (El Idrissi and Corbett, 2016). Deep concerns have been raised about the increasing energy demands for powering and cooling of business data centres, their subsequent costs and rising carbon emissions (Uddin and Rahman, 2012), as well as the growing problem of e-waste (Molla and Abareshi, 2012). Paradoxically, when used judiciously, IT can turn into a powerful business ally for environmental sustainability (Chen, Boudreau and Watson 2008). Businesses across the world appear to have understood this as they invest more in energy-efficient IT devices and IT solutions (GeSI 2015). As predicted in the \#SMARTer2030 ICT Solutions for the 21st Century Challenges report, such rise in Green IT investment will result in a $20 \%$ global carbon emission reduction and a decrease of ITreleased carbon to $1.97 \%$ by 2030 (GeSI 2015). Green IT investments also carry several business benefits such reduced costs (Cai et al., 2013) and increased environmental firm performance (Xia et al., 2014) which result in greater business competitiveness,

Yet, despite realising the importance of IT Governance and Green IT to optimise business IT value and sustainability (Hanne 2011), Green IT remains a concern in developing countries, 
especially due to their perceived lack of Green IT awareness (Chugh et al., 2016) and low Green IT maturity levels as compared to their developed counterparts (Wabwoba et al., 2013). SIDS with high IT dependency and extreme vulnerability to the dangers of climate change, such as Mauritius, are no different.

\subsection{IT Governance and Green IT in Mauritius}

From its economic blue-print for the achievement of high income status by 2025 (Kalumiya and Kannan, 2015) to its 2017-2018 budget announcements ("Budget Speech 2017-2018," 2017), the Mauritian government strives to turn Mauritius into a prominent IT hub and a digital economy. Environmental sustainability also runs high on the island's agenda. The World Bank (2015) ranks Mauritius in its list of top ten countries with high exposure to natural disasters, and the island occupies the $13^{\text {th }}$ position on the 2017 WorldRisklndex for environmental vulnerabilities ("World Risk Report Analysis and Prospects," 2017). Mauritius is also not proud of its carbon emissions which rose by 3.8\% in 2015 (Statistics Mauritius, 2015). Such environmental issues resulted in the Mauritian government's "Maurice lle Durable" (MID) project for environmentally sustainable behaviours (The Ministry of Environment and Sustainable Development, 2011). Ecological concerns are also noted in the island's 2030 vision in which it pledges a 30\% reduction in Greenhouse Gas (GHG) emissions, and Intended Nationally Determined Contributions (INDCs) submitted to the United Nations Framework Convention on Climate Change (UNFCC) for the 2015 Paris Climate Conference (Government of Mauritius, 2015). Realising the importance of IT in this quest for sustainability, the Ministry of Information and Communication Technology (2013) came up with a national Green ICT policy, but this has been withheld since the change in government in 2015. An IT Governance and Green IT model is therefore essential to better guide Mauritian organisations in optimising IT potential for business value and sustainability. This is discussed next.

\section{Conceptual research model}

The first step in developing the conceptual ITGM was to recognise key IT Governance and Green IT constructs from literature. Two main dimensions of ITG were thus identified: (1) IT decisions and their accountability archetypes (Weill, 2004), and (2) ITG mechanisms (De Haes and Van Grembergen, 2009). These were followed by Molla et al.'s (2011) five essential mechanisms for organisational Green IT readiness. All constructs are summarised and explained in Table 1. 
Table 1: Summary of key IT Governance and Green IT constructs

\begin{tabular}{|c|c|}
\hline \multicolumn{2}{|r|}{ IT Decisions Weill(2004) } \\
\hline IT principles & Provide guidelines for organisational IT use \\
\hline IT architecture & Refer to policies governing technical IT choices \\
\hline IT infrastructure & $\begin{array}{l}\text { Determine hardware/software and IT human resource } \\
\text { requirements }\end{array}$ \\
\hline Business application needs & $\begin{array}{l}\text { Justify the choice of either off-the-shelf or tailor-made } \\
\text { IT solutions }\end{array}$ \\
\hline IT investment and prioritisation & Determine the selection of IT projects and their cost \\
\hline \multicolumn{2}{|c|}{ IT Decision Accountabilities referred to as IT Governance Archetypes (Weill 2004) } \\
\hline Business monarchy & $\begin{array}{l}\text { Business executives are accountable (may also include } \\
\text { IT executives). }\end{array}$ \\
\hline IT monarchy & Only IT executives are accountable. \\
\hline Feudal & $\begin{array}{l}\text { Individual business units or functions take their own IT } \\
\text { decisions. }\end{array}$ \\
\hline Federal & $\begin{array}{l}\text { Business executives, Business Unit (BU) leaders, and } \\
\text { sometimes, IT executives collaboratively take the IT } \\
\text { decision. }\end{array}$ \\
\hline IT duopoly & $\begin{array}{l}\text { IT executives together with either business executives } \\
\text { or BU leaders hold the IT the decision accountability }\end{array}$ \\
\hline Anarchy & Individual users take their own IT decision \\
\hline \multicolumn{2}{|c|}{ IT Governance Mechanisms (De Haes and Van Grembergen 2009) } \\
\hline Structures & $\begin{array}{l}\text { Formal executive positions or IT committees which } \\
\text { connect IT and business in strategic IT decision-making }\end{array}$ \\
\hline Processes & $\begin{array}{l}\text { Methodologies that assist IT decision-taking and } \\
\text { monitoring }\end{array}$ \\
\hline Relational mechanisms & $\begin{array}{l}\text { Active involvement and collaboration among } \\
\text { executives, IT and business management for the } \\
\text { realisation of IT and business goals }\end{array}$ \\
\hline \multicolumn{2}{|c|}{ Green IT Mechanisms (Molla et al. 2011) } \\
\hline Green IT attitude & Ecological beliefs of business and IT leaders \\
\hline Green IT policy & $\begin{array}{l}\text { Formal guidance for the successful implementation of } \\
\text { Green IT }\end{array}$ \\
\hline Green IT practice & $\begin{array}{l}\text { For environmentally sustainable considerations in the } \\
\text { purchase, use and disposal of IT }\end{array}$ \\
\hline Green IT technology & $\begin{array}{l}\text { Information technology that promotes energy- } \\
\text { efficiency and carbon emission reduction }\end{array}$ \\
\hline Green IT governance & $\begin{array}{l}\text { For Green IT decision accountability, budgeting, } \\
\text { monitoring and reporting }\end{array}$ \\
\hline
\end{tabular}

Given the importance of ITG in efficient and clean IT use, the initial ITGM shown in Figure 1 was developed by merging ITG decisions and accountabilities (archetypes) with the ITG mechanisms and the first four Green IT constructs described in Figure 1. Green IT was added to the model as an additional IT decision to complement those identified by Weill (2004), since it was found to be increasingly considered in strategic IT. ITG and Green IT mechanisms support ITG decision accountabilities. The fifth G-Readiness construct, Green IT governance (Molla and Cooper, 2009), is not included as a Green IT mechanism since it is a part of the other two sections of the model (IT decision accountabilities and governance mechanisms). 


\section{IT GOVERNANCE MECHANISMS}

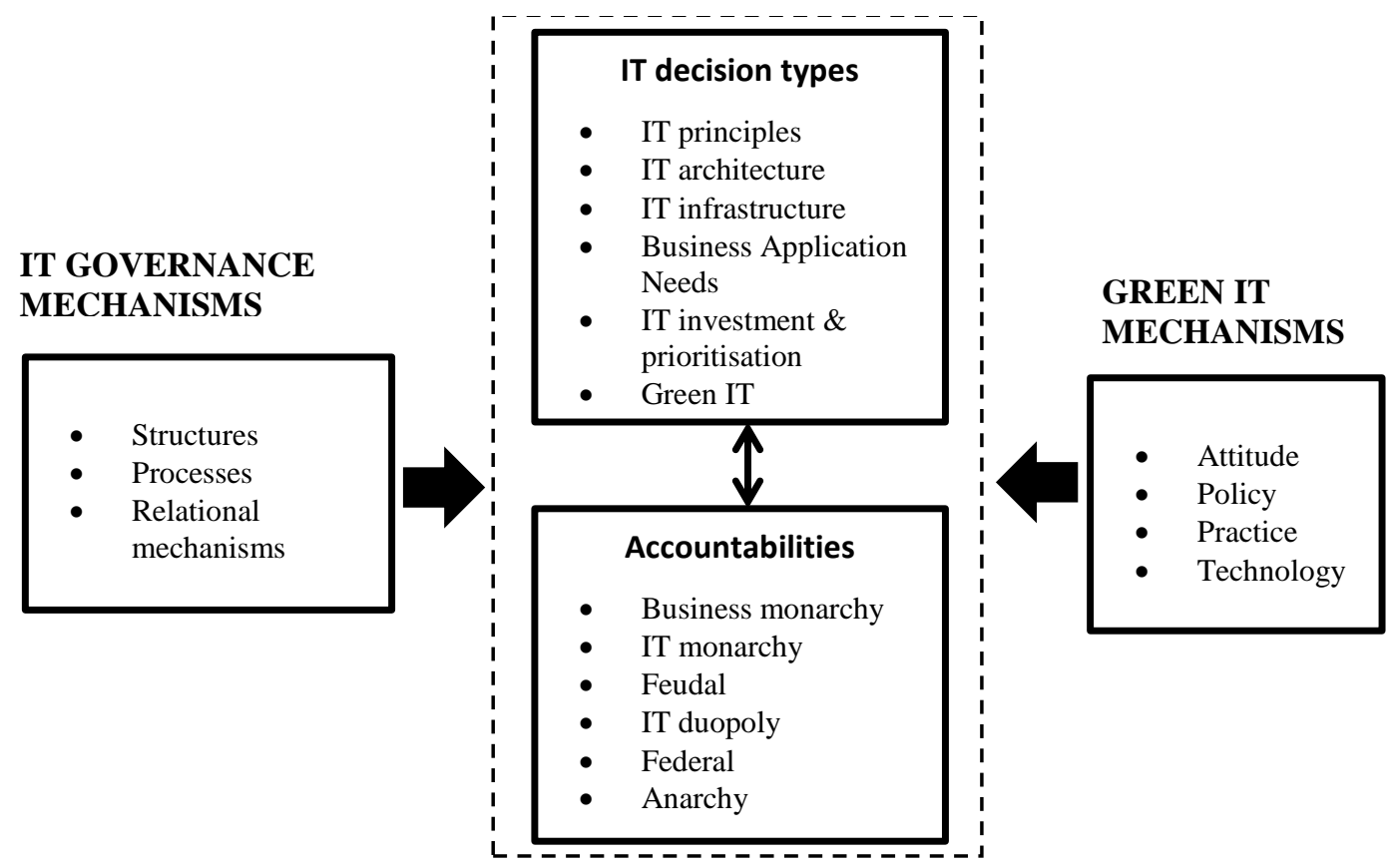

\section{IT DECISION ACCOUNTABILITIES}

Figure 1: Conceptual IT Governance and Green IT model (Adapted from Weill (2004), De Haes and Van Grembergen (2009), Molla and Cooper (2009))

\section{Research design}

Data collection consisted of a survey of large companies belonging to the five main pillars of the Mauritian economy namely, namely: finance, tourism, ICT, textile and sugar industries (The World Bank, 2015). Large companies were targeted due to their greater inclination for IT Governance (Debreceny, 2013), and keener interest in Green IT endeavours triggered by their high energy consumption, resource availability and technical expertise (Molla and Abareshi, 2011). Aligning with the Mauritian Small and Medium Enterprises Development Authority (SMEDA) Act 2009, large organisations were defined as companies generating an annual turnover exceeding 50 million rupees. The Mauritian private sector was also prioritised owing to its dominance in the island's economy.

The survey questionnaire was developed using relevant literature for content validity. Apart from eliciting demographical information, the questionnaire was structured into the following four sections: IT decision accountabilities, IT Governance mechanisms, Green IT mechanisms, and IT Governance and Green IT influencers. The survey was administered to both executives ( $\mathrm{CxOs}$ ) and IT managers from the company population identified. This is because IT Governance is not only the prime responsibility of executives, but it also needs to be understood and implemented by IT managers (Willson and Pollard, 2009).

The population of large organisations from the five main pillars of the Mauritian economy is shown in Table 2, and was first identified using the 2007 database of companies available from the Central Statistical Office (CSO) of Mauritius, now known as Statistics Mauritius. Since this was the only database available at the time of the research, the sampling frame was further refined by calling the companies involved and checking their websites to discover closures and mergers. The population of eligible companies was also updated by consulting company directories such as the 2012 directory of IT companies. Questionnaires were sent 
to all the companies in the sampling frame due to the $35 \%$ - $40 \%$ acceptable response rate of executives and high-level managers reported by Baruch and Holtom (2008). As can be seen from Table 2, 109 out of the 192 companies identified participated in the research, and a total of 128 questionnaires were compiled out of which 121 were valid (seven questionnaires were incomplete and therefore rejected). The company response rate was therefore $56.8 \%$ and above the acceptable upper range of $40 \%$ advocated by Baruch and Holtom (2008). $63.9 \%$ of non-participants provided reasons. These ranged from being too busy (38\%), to a lack of interest in the research (18\%) to confidentiality issues (7.9\%). Survey demographics data also identified $58.7 \%$ of respondents as being IT managers, $21.5 \%$ as business executives and $19.8 \%$ as IT executives. $91.8 \%$ of companies belonged to the private sector as compared to $3.3 \%$ from the public sector and $5 \%$ from the parastatal group. This was expected due to the private sector dominance in key Mauritian economic sectors.

Table 2: Details of survey response

\begin{tabular}{|c|c|c|c|c|}
\hline \multirow{2}{*}{ Industry } & \multirow{2}{*}{$\begin{array}{c}\text { Target } \\
\text { population }\end{array}$} & $\begin{array}{c}\text { Number of } \\
\text { participating } \\
\text { companies }\end{array}$ & \multicolumn{2}{|c|}{ Number of questionnaires } \\
\cline { 4 - 5 } & & 13 & 13 & Total received \\
\hline Textile & 50 & 2 & 3 & 3 \\
\hline Sugar & 4 & 32 & 38 & 35 \\
\hline Finance & 43 & 49 & 61 & 13 \\
\hline IT & 75 & 13 & 13 & $\mathbf{1 2 1}$ \\
\hline Tourism & 20 & $\mathbf{1 0 9}$ & $\mathbf{1 2 8}$ & \\
\hline TOTAL & $\mathbf{1 9 2}$ & & & \\
\hline
\end{tabular}

Survey data was then analysed using Principal Component Analysis (PCA) followed by Confirmatory Factor Analysis (CFA). SPSS 21.0 and Lisrel 8.80 were used to run the PCA and CFA respectively. CFA was effected using polychoric correlations with weighted least squares (WLS). Due to the small sample size, a parallel model with all latent variable items constrained to be equal, was preferred for improved model accuracy (Molla, Cooper and Pittayachawan 2011). Model fit was indicated by a non-significant $(p>0.05)$ and small chi-square $\left(\chi^{2}\right)$ value relative to its degrees of freedom ( $d f$ ) (Dyer et al., 2005) coupled with the following goodness of fit index range: Root Mean Square Error Of Approximation (RMSEA) $\leq 0.06$; Standardised Root Mean Residual (SRMR) $\leq 0.08$ (Hu and Bentler 1998); Comparative Fit Index (CFI) > 0.9; Non-Normed Fit Index (NNFI) > 0.9 (Hu and Bentler 1999); Parsimonious Fit Index (PNFI) > 0.5 (Mulaik et al., 1989). In case of model unfit, variables with modification index (MI) above 5 (Gefen, 2003) and standardised residuals exceeding 2.58 (Segars and Grover 1993) were removed. Unidimensional validity or affirmation that an item relates to only one factor, was based on MI values less than 5 to indicate the absence of cross-loadings (Gefen, 2003). Convergent validity or the extent to which factor items are related to each other, was demonstrated by statistically insignificant $(p>0.05) \chi^{2}$ and factor loadings $(\lambda)>0.707$ (Straub, Boudreau and Gefen 2004). Where a mechanism or influencer had more than one factor, discriminant validity and factorial validity had to be determined. Discriminant validity or confirmation that factors were unrelated to each other was ascertained using a $\chi^{2}$ test of difference on factor pairs to demonstrate a statistically significant lower value for the unconstrained model (correlation between factors set free) as opposed to the constrained one (correlation between factors set to 1) (Anderson and Gerbing, 1988). Factorial validity was indicated by valid goodness-of-fit indices (Straub et al., 2004).

\section{Results}

\subsection{IT Decision Accountabilities}


Table 3 shows a summary of IT accountability survey responses across IT decision types identified in Figure 1. Since IT duopolies comprise of joint decision accountability between IT executives and either BU or business executives (Weill 2004), each accountability pair (IT \& BU leaders; IT \& business executives) was treated as a separate column in Table 3. Business monarchies may or may not include IT executives (Weill 2004), hence the differentiation between the two in Table 3. Weill (2004) also states that the collaborative IT decision accountability of business and IT executives can either take the form of a business monarchy where the IT executive sits on the board of directors and shares responsibility with other board members for the IT decision, or an IT duopoly where the IT executive teams up with business executives for IT decision accountability. Both these archetypes were grouped under one column as they involve joint accountability of business and IT executives. The federal IT decision archetype may or may not include IT heads (Weill 2004); hence the two columns for the federal accountability mode. None of the survey responses attributed IT decision responsibility to individual users, thus explaining the absence of the anarchy archetype in Table 3.

IT accountability archetype preferences were then deduced based on highest frequencies (shown in red). The IT monarchy archetype was clearly the most popular mode of IT decision accountability. IT executives or heads thus appear to be primarily answerable for IT and Green IT decisions. The only exception lies in IT investment and prioritisation decisions for which both IT and business executives were found to be most commonly accountable.

Table 3: Summary of survey responses for IT accountabilities across IT decision types

Accountabilities

\begin{tabular}{|c|c|c|c|c|c|c|c|}
\hline IT decisions & $\begin{array}{c}\text { Business } \\
\text { monarchy } \\
\text { (business } \\
\text { executives } \\
\text { only) }\end{array}$ & $\begin{array}{c}\text { IT } \\
\text { monarchy } \\
\text { (IT } \\
\text { executives } \\
\text { /Heads } \\
\text { only) }\end{array}$ & $\begin{array}{c}\text { IT } \\
\text { duopoly } \\
\text { (IT \& BU } \\
\text { leaders) }\end{array}$ & $\begin{array}{l}\text { IT duopoly } \\
\text { (IT \& } \\
\text { business } \\
\text { executives) } \\
\text { OR business } \\
\text { monarchy } \\
\text { (executives } \\
\text { including IT } \\
\text { executive) }\end{array}$ & $\begin{array}{c}\text { Federal } \\
\text { (business } \\
\text { executives } \\
\& \text { BU } \\
\text { leaders) }\end{array}$ & $\begin{array}{c}\text { Federal } \\
\text { (business } \\
\text { executives } \\
\text {, IT Heads } \\
\& \text { BU } \\
\text { leaders) }\end{array}$ & $\begin{array}{l}\text { Feudal } \\
\text { (BU } \\
\text { leaders } \\
\text { only) }\end{array}$ \\
\hline $\begin{array}{c}\text { IT investment \& } \\
\text { prioritisation }\end{array}$ & 12 (9.9\%) & $31(25.6 \%)$ & $\begin{array}{c}15 \\
(12.4 \%)\end{array}$ & $43 \quad(35.5 \%)$ & $2 \quad(1.7 \%)$ & 15 (12.4\%) & $\begin{array}{c}3 \\
(2.5 \%)\end{array}$ \\
\hline $\begin{array}{l}\text { Business } \\
\text { application } \\
\text { needs }\end{array}$ & $10(8.3 \%)$ & 33 (27.3\%) & $\begin{array}{c}20 \\
(16.5 \%)\end{array}$ & $33 \quad(27.3 \%)$ & $1 \quad(0.8 \%)$ & 14 (11.5\%) & $\begin{array}{c}10 \\
(8.3 \%)\end{array}$ \\
\hline IT infrastructure & $10 \quad(8.3 \%)$ & $53(43.8 \%)$ & $\begin{array}{c}16 \\
(13.2 \%)\end{array}$ & $30 \quad(24.8 \%)$ & $1 \quad(0.8 \%)$ & $6 \quad(5.0 \%)$ & $\begin{array}{c}5 \\
(4.1 \%)\end{array}$ \\
\hline IT architecture & $13(10.7 \%)$ & 67 (55.4\%) & $\begin{array}{c}11 \\
(9.1 \%)\end{array}$ & $24 \quad(19.9 \%)$ & $(0 \%)$ & $5 \quad(4.1 \%)$ & $\begin{array}{c}1 \\
(0.8 \%)\end{array}$ \\
\hline IT principles & $13(10.7 \%)$ & 66 (54.6\%) & $\begin{array}{c}13 \\
(10.7 \%)\end{array}$ & $21 \quad(17.4 \%)$ & $(0 \%)$ & $3 \quad(2.5 \%)$ & $\begin{array}{c}5 \\
(4.1 \%)\end{array}$ \\
\hline Green IT & $17(14.1 \%)$ & $58(47.9 \%)$ & $\begin{array}{c}12 \\
(9.9 \%)\end{array}$ & $18 \quad(14.9 \%)$ & $(0 \%)$ & $\begin{array}{c}11 \\
(9.1 \%)\end{array}$ & $\begin{array}{c}5 \\
(4.1 \%)\end{array}$ \\
\hline
\end{tabular}

\subsection{IT Governance Mechanisms}

Several IT Governance mechanisms appeared to be common among the businesses explored. As shown in Table 4, CFA results confirmed IT and steering committees for strategic IT decisions (including Green IT) as commonly implemented IT Governance structures. The presence of both business and IT Heads on IT steering committees was also affirmed. Process mechanisms including IT strategic planning, yearly IT budgeting, the implementation of risk 
management frameworks and the need for IT Heads to be constantly aware of relevant IT innovations were found to be commonly implemented. In addition, survey analysis identified the presence of two relational mechanism factors shown in Table 4. Once their discriminant validity (Table 5) and factorial validity (Table 6) established, business and IT communication, IT knowledge management, as well as the implementation of systems and processes for Green IT employee awareness emerged as relational mechanisms. 


\section{Table 4: Summary of model fit and convergent validity results for IT Governance mechanisms}

\begin{tabular}{|c|c|c|c|c|c|c|c|c|c|c|c|c|}
\hline \multirow{2}{*}{ Construct } & \multirow{2}{*}{ Factor } & \multirow{2}{*}{ Items } & \multicolumn{10}{|c|}{ Factor loading $(\lambda)$, Cronbach $\alpha$ and goodness-of-fit indices** } \\
\hline & & & $\lambda$ & $\alpha$ & $x^{2}$ & $d f$ & $\mathbf{p}$ & RMSEA & SRMR & NNFI & CFI & PNFI \\
\hline Structures & STRU & $\begin{array}{l}\text { IT executive committee oversees strategic IT } \\
\text { decisions; } \\
\text { IT steering committee oversees strategic IT } \\
\text { decisions; }\end{array}$ & 0.86 & 0.82 & 3.10 & 2 & 0.21 & 0.06 & 0.06 & 0.99 & 0.99 & 0.65 \\
\hline Processes & PRO & $\begin{array}{c}\text { Organisational strategic IT defined to align } \\
\text { with business strategy; } \\
\text { IT budget is assigned yearly; } \\
\text { IT risk management follows company risk } \\
\text { management framework; } \\
\text { IT executives/Heads scan for useful } \\
\text { technological innovations. }\end{array}$ & 0.77 & 0.76 & 7.24 & 5 & 0.20 & 0.06 & 0.06 & 0.98 & 0.98 & 0.78 \\
\hline \multirow[t]{2}{*}{$\begin{array}{l}\text { Relational } \\
\text { Mechanisms }\end{array}$} & RM1 & $\begin{array}{c}\text { Regular meetings unite business \& IT Heads } \\
\text { for IT decisions; } \\
\text { Systems to distribute IT Governance } \\
\text { knowledge are established; } \\
\text { Processes to distribute IT } \\
\text { Governance knowledge are established. }\end{array}$ & 0.79 & 0.77 & 0.04 & 2 & 0.98 & 0.00 & 0.01 & 1.03 & 1.00 & 0.67 \\
\hline & RM2 & $\begin{array}{c}\text { Systems spreading Green IT awareness } \\
\text { among employees are established; } \\
\text { Processes for Green IT employee awareness } \\
\text { are established. }\end{array}$ & 0.82 & 0.79 & 0 & 0 & 1 & 0.00 & 0.00 & 1 & 1 & 1 \\
\hline
\end{tabular}

** $\chi 2$ - chi squared; df - degrees of freedom; Root Mean Square Error Of Approximation - RMSEA; Standardised Root Mean Residual - SRMR; Comparative Fit Index - CFI; Non-Normed Fit Index - NNFI; Parsimonious Fit Index - PNFI. 
Table 5: Summary of discriminant validity results for relational mechanism factors

\begin{tabular}{|c|c|c|c|c|c|c|c|}
\hline \multirow{2}{*}{ Construct } & \multirow{2}{*}{\multicolumn{2}{|c|}{$\begin{array}{l}\text { Factor } \\
\text { pairs }\end{array}$}} & \multicolumn{3}{|c|}{$x^{2}$} & \multirow{2}{*}{$d f$} & \multirow{2}{*}{$p$} \\
\hline & & & Constrained & Unconstrained & Difference & & \\
\hline Relational Mechanisms & RM1 & RM2 & 20.93 & 5.65 & 15.28 & 1 & 0.000 \\
\hline
\end{tabular}

Table 6: Summary of factorial validity results for relational mechanism factors

\begin{tabular}{|c|c|c|c|c|c|c|c|c|c|}
\hline \multirow{2}{*}{ Construct } & \multirow{2}{*}{ Factor } & \multicolumn{7}{|c|}{ Factorial validity goodness-of-fit indices } \\
\cline { 2 - 10 } & & $\mathbf{X}$ & $\boldsymbol{d} \boldsymbol{f}$ & $\boldsymbol{p}$ & RMSEA & SRMR & NNFI & CFI & PNFI \\
\hline $\begin{array}{c}\text { Relational } \\
\text { Mechanisms }\end{array}$ & $\begin{array}{c}\text { RM1; } \\
\text { RM2 }\end{array}$ & 5.65 & 7 & 0.58 & 0.00 & 0.06 & 1.01 & 1.00 & 0.68 \\
\hline
\end{tabular}

\subsection{Green IT mechanisms}

Analysis of survey findings revealed the implementation of a number of Green IT mechanisms to promote environmental sustainability. For example, as documented in Table 7, Green IT leadership as well as a concern for IT energy efficiency and environmentally responsible ewaste disposal were found to be a common Green IT attitude. Table 7 also indicates that policies for environmentally sustainable behaviour, Green IT acquisition and ecologically friendly IT usage are popular mechanisms among the companies surveyed. Some Green IT practices were also confirmed. These were classified as 'Greening IT' practices where IT is used ecologically, and 'Greening by IT' measures where IT is used to promote environmentally friendly business processes. 'Greening IT' practices include a preference for environmentally concerned IT suppliers, frequent technology updates for energy efficiency, as well as Green IT infrastructure design. E-transactions and ecological printing were found to be practised for 'Greening by IT'. The adoption of Green technology mechanisms including virtualisation and energy-efficient lighting in areas such as server rooms were also identified to be a common trend. 
Table 7: Summary of model fit and convergent validity results for Green IT mechanisms

\begin{tabular}{|c|c|c|c|c|c|c|c|c|c|c|c|c|}
\hline \multirow{2}{*}{ Construct } & \multirow{2}{*}{ Factor } & \multirow{2}{*}{ Items } & \multicolumn{10}{|c|}{ Factor loading $(\lambda)$, Cronbach $\alpha$ and goodness-of-fit indices ${ }^{* *}$} \\
\hline & & & $\lambda$ & $\alpha$ & $x^{2}$ & $d f$ & $\mathbf{p}$ & RMSEA & SRMR & NNFI & CFI & PNFI \\
\hline Green IT Attitude & GAT & $\begin{array}{l}\text { Organisational concern about its IT energy } \\
\text { consumption; } \\
\text { Organisational concern about its environmental } \\
\text { impact on IT disposal; } \\
\text { Green IT initiatives are driven by organisational } \\
\text { leader(s). }\end{array}$ & 0.84 & 0.83 & 1.32 & 2 & 0.52 & 0.00 & 0.05 & 1.01 & 1.00 & 0.66 \\
\hline Green IT Policy & GPO & $\begin{array}{c}\text { Organisation has an environmental } \\
\text { sustainability policy; } \\
\text { Organisation has a purchasing policy including } \\
\text { Green IT acquisition; } \\
\text { Organisation has a policy for environmentally } \\
\text { friendly IT use. }\end{array}$ & 0.91 & 0.89 & 1.29 & 2 & 0.52 & 0.00 & 0.07 & 1.00 & 1.00 & 0.66 \\
\hline Green IT Practice & GPR & $\begin{array}{l}\text { Organisation prefers environmentally } \\
\text { responsible IT suppliers; } \\
\text { Technology is upgraded for improved energy } \\
\text { efficiency; } \\
\text { Organisation provides e-transaction facilities; } \\
\text { Environmental factors are considered in the } \\
\quad \text { design of IT infrastructure; } \\
\text { Organisation encourages Green printing. }\end{array}$ & 0.84 & 0.86 & 7.26 & 9 & 0.61 & 0.00 & 0.04 & 1.00 & 1.00 & 0.88 \\
\hline Green technology & GTE & $\begin{array}{l}\text { Storage virtualisation; } \\
\text { Desktop virtualisation; } \\
\text { Energy-efficient lighting; }\end{array}$ & 0.75 & 0.72 & 1.05 & 2 & 0.59 & 0.00 & 0.04 & 1.02 & 1.00 & 0.66 \\
\hline
\end{tabular}

** $\chi 2$ - chi squared; df - degrees of freedom; Root Mean Square Error Of Approximation - RMSEA; Standardised Root Mean Residual - SRMR; Comparative Fit Index - CFI; Non-Normed Fit Index - NNFI; Parsimonious Fit Index - PNFI. 


\subsection{IT Governance and Green IT influencers}

ITG and Green IT influencers emerging from this study were classified as ITG drivers, Green IT drivers and Incentives and Support. Quality certifications and accreditations such a membership in the Leading Hotels of the World Consortium (LHW) were found to drive ITG practice. Global economic turbulences and the resulting need for industry resilience were also identified as ITG drivers. For example, one of the companies studied, attributed their revamped IT strategic plan to the need for improved risk management and efficiency. Other ITG drivers include existing laws such as those enforcing IT efficiency, as well as expected changes to the legal framework which could bring obligations such as mandatory external IT audits. Client expectations and the political vision of turning Mauritius into an ICT hub also emerged as ITG motivating factors. Following discriminant and factorial validity analysis shown in Table 9 and Table 10 respectively, survey results reported in Table 8 also validated the presence of several Green IT drivers. These include certifications such as ISO 14067 requiring IT carbon footprint monitoring and reporting, industry resilience benefits resulting from an environmentally sustainable business, and the environmental concerns of stakeholders (clients, competitors and society at large). Results also pointed towards incentives such as Green IT tax benefits (e.g. 50\% tax rebate on Green technology) and Green IT awards for environmentally responsible behaviours. Governmental support mechanisms for ITG and Green IT such as guidelines provided by the National Computer Board were also reported as useful.

\subsection{The IT Governance and Green IT model}

The final ITGM (Figure 2) was compiled from the IT decision accountabilities, IT Governance and Green IT mechanisms, ITG and Green IT influencers emerging from CFA results. The arrows from ITG and Green IT mechanisms pointing towards IT decision accountabilities designate the need for such mechanisms to facilitate IT decision taking. Similarly, the arrow from ITG and Green IT influencers to IT decision accountabilities indicates the influence of these drivers, incentives and support mechanism on IT decisions and their accountabilities. 
Table 8: Summary of model fit and convergent validity results for IT Governance and Green IT influencers

\begin{tabular}{|c|c|c|c|c|c|c|c|c|c|c|c|c|}
\hline \multirow{2}{*}{ Construct } & \multirow{2}{*}{ Factor } & \multirow{2}{*}{ Items } & \multicolumn{10}{|c|}{ Factor loading $(\lambda)$, Cronbach $\alpha$ and goodness-of-fit indices ${ }^{* *}$} \\
\hline & & & $\lambda$ & $\alpha$ & $x^{2}$ & $d f$ & $\mathbf{p}$ & RMSEA & SRMR & NNFI & CFI & PNFI \\
\hline $\begin{array}{l}\text { IT Governance } \\
\text { drivers }\end{array}$ & IGD & $\begin{array}{c}\text { Current Mauritian legislation; } \\
\text { Suggested amendments to the Mauritian } \\
\text { Regulatory Framework; } \\
\text { Political strategy of turning Mauritius into an ICT } \\
\text { hub; } \\
\text { Client expectations. }\end{array}$ & 0.79 & 0.79 & 2.66 & 5 & 0.75 & 0.00 & 0.05 & 1.02 & 1.00 & 0.82 \\
\hline \multirow{2}{*}{ Green IT drivers } & GID1 & $\begin{array}{l}\text { The acquisition of certifications or accreditations } \\
\text { endorsing environmental responsibility; } \\
\text { Industry resilience. }\end{array}$ & 0.85 & 0.79 & 0.00 & 0 & 1 & 0.00 & 0.00 & 1 & 1 & 1 \\
\hline & GID2 & $\begin{array}{l}\text { Clients' environmental concern; } \\
\text { Competitors' environmental concern; } \\
\text { Society's environmental concern. }\end{array}$ & 0.91 & 0.91 & 0.31 & 2 & 0.85 & 0.00 & 0.01 & 1.02 & 1.00 & 0.67 \\
\hline $\begin{array}{l}\text { Incentives \& } \\
\text { Support } \\
\text { Mechanisms }\end{array}$ & GGI & $\begin{array}{c}\text { Tax benefits on Green IT equipment; } \\
\text { Green IT Governance awards; } \\
\text { Government-provided IT Governance support } \\
\text { units. }\end{array}$ & 0.87 & 0.84 & 2.62 & 2 & 0.27 & 0.05 & 0.04 & 1.00 & 1.00 & 0.66 \\
\hline
\end{tabular}

** $\chi 2$ - chi squared; df - degrees of freedom; Root Mean Square Error Of Approximation - RMSEA; Standardised Root Mean Residual - SRMR; Comparative Fit Index - CFI; Non-Normed Fit Index - NNFI; Parsimonious Fit Index - PNFI.

Table 9: Summary of discriminant validity results for Green IT drivers

\begin{tabular}{|c|c|c|c|c|c|c|c|}
\hline \multirow{2}{*}{ Construct } & \multirow{2}{*}{\multicolumn{2}{|c|}{ Factor pairs }} & \multicolumn{3}{|c|}{$x^{2}$} & \multirow{3}{*}{$d f$} & \multirow{2}{*}{$p$} \\
\hline & & & Constrained & Unconstrained & Difference & & \\
\hline Green IT drivers & GID1 & GID2 & 48.72 & 41.74 & 6.98 & & 0.008 \\
\hline
\end{tabular}

Table 10: Summary of factorial validity results for Green IT drivers

\begin{tabular}{|c|c|c|c|c|c|c|c|c|c|}
\hline \multirow{2}{*}{ Construct } & \multirow{2}{*}{ Factor } & \multicolumn{8}{|c|}{ Factorial validity goodness-of-fit indices } \\
\hline & & $x^{2}$ & $d f$ & $p$ & RMSEA & SRMR & NNFI & CFI & PNFI \\
\hline Green IT drivers & GID1; GID2 & 3.73 & 7 & 0.81 & 0.00 & 0.04 & 1.01 & 1.00 & 0.69 \\
\hline
\end{tabular}




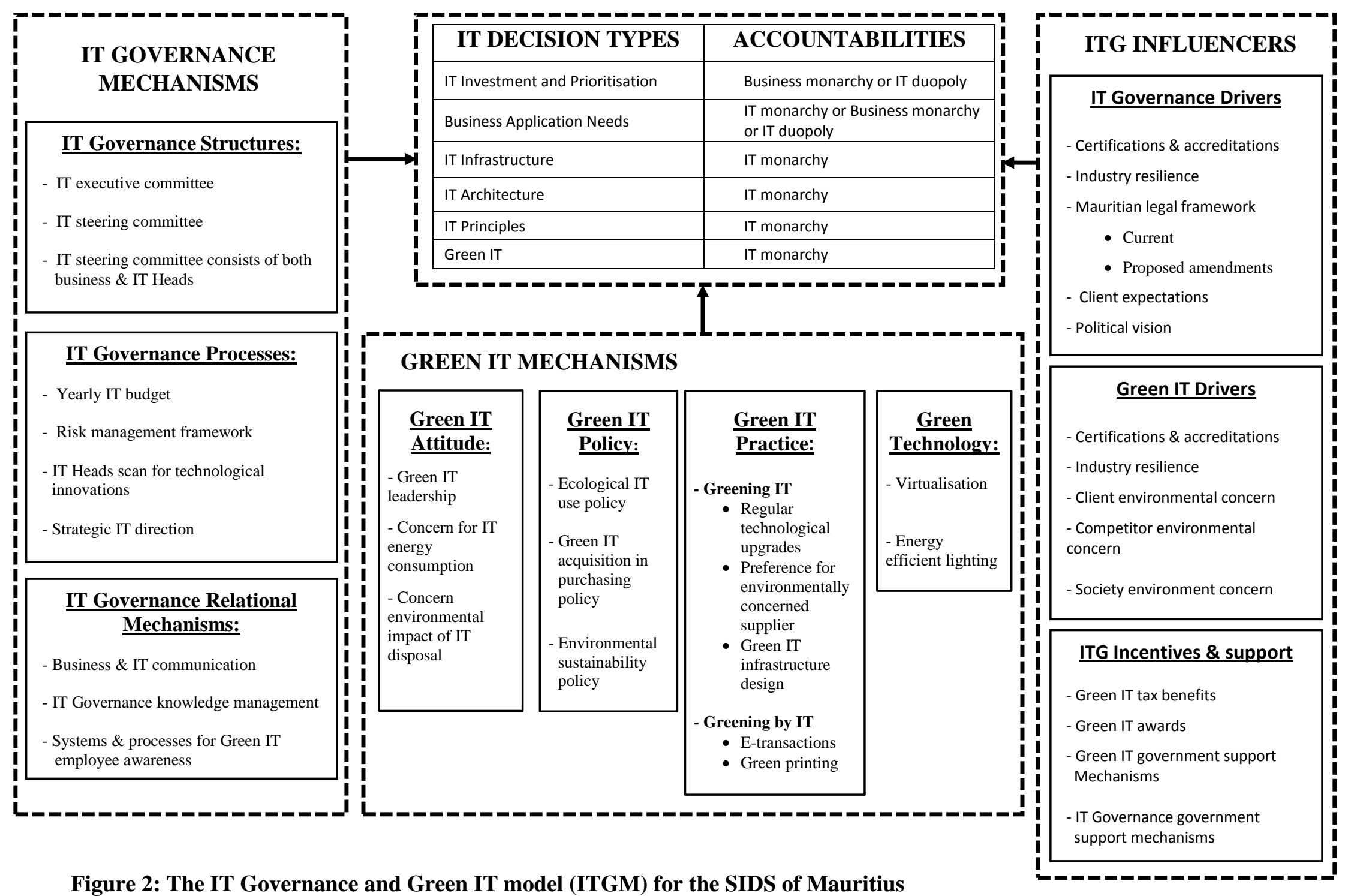




\section{Results, Discussion and New Findings}

Figure 2 clearly indicates that IT Governance and Green IT figure on the large Mauritian company agenda, and are driven by a number of factors which align closely with previous literature. These include certifications to endorse sustainable IT practice (Bohas and Poussing, 2016), business resilience (Vykoukal et al., 2009), legislations (Bose and Luo, 2012; Murugesan, 2008) and expectations of stakeholders such as customers (Molla and Abareshi, 2012), competitors (Watson et al., 2010) and society at large (Bansal and Roth, 2000). These drivers are further encouraged by the political drive for IT sustainability excellence supported by government structures, environmental awards, and tax benefits (Wang and Chang, 2014).

The ITGM also shows a dominance of IT monarchies in the governance of most IT decision types including infrastructural, architectural, IT usage and Green IT decisions. This accountability preference also shows an inclination towards a centralised approach which favours enterprise-wide synergy for higher profits and greater executive control (Sohal and Fitzpatrick, 2002). Findings also indicate a strong IT and business executive interest in strategic IT ventures. This is supported by an inclination for business monarchies or IT duopolies to underlie IT investment decisions.

Several IT Governance and Green IT mechanisms prevail in large Mauritian companies. IT committees and a combination of business and IT representatives on IT steering committees are common ITG structures. This further enforces collaborative IT decisions which are essential for effective ITG (Ferguson et al., 2013). The presence of Green IT governance structures for collaborative business and IT buy-in for Green IT commitment also emerged. Such organisational structures are essential to foster a positive attitude towards the environment (Melville, 2010), and reinforce Green IT values and belief among IT professionals (Molla et al., 2014).

ITG processes identified in the ITGM include yearly IT budgets recommended in literature by Jairak, Praneetpolgrang, and Subsermsri (2015) for IT investment control, risk management framework for effective IT risk management (Bradley et al., 2012), strategic IT plans for IT decisions to be driven by an IT vision (Willson and Pollard, 2009), and an awareness of IT innovations for a competitive edge (Ali et al., 2013). Such processes support wise IT including Green IT decision-taking among the businesses surveyed.

Commonly implemented relational mechanisms include business and IT communication, viewed as a key requirement for business and IT alignment (Roses et al., 2015), as well as ITG knowledge management and employee Green IT awareness. The organisations studied are thus committed to sharing ITG processes and practices for improved understanding and implementation as supported by Bin-Abbas and Bakry (2014), and support employee Green IT awareness which is essential for Green IT commitment (Chugh et al., 2016).

The presence of Green IT leadership along with concerns for energy efficiency and sustainable e-waste disposal to promote Green IT practice is also noted. This aligns with literature which identifies a positive relationship between Green IT attitude and the adoption of Green IT practice, and shows top level commitment for a Green IT culture supportive of environmentally-conducive behaviour changes (Mishra et al., 2014). Green IT policies guiding Green IT acquisition, disposal and environmentally sustainable behaviours also exist. These are essential to provide organisational Green IT guidance (Bai et al., 2017; Bohas and Poussing, 2016) and support Green IT practices including a preference for energy-efficient IT 
('Greening IT'), and IT use to promote environmental responsibility ('Greening by IT'). 'Greening IT' practices are indicated by a penchant for environmentally friendly IT suppliers as recommended by Erek et al. (2009), regular technological upgrades for energy efficiency encouraged by Bose and Luo (2012), and Green IT infrastructure design such as ecological data centre designs advocated by Ardito and Morisio (2014). 'Greening by IT' measures comprise of e-transactions for paperless processes, and efficient printing such as centralised and/or double-sided printing. Green technology such as virtualisation and energy efficient lighting in areas such as server rooms were also identified. Both these techniques are strongly recommended by Chuang and Hang (2014) and Bai et al. (2017) for business environmental responsibility.

While the ITGM shows IT Governance and Green IT promise, there remains room for improvement. For example, an IT presence on organisational boards would help in better championing strategic IT decisions (including Green IT) for business benefit (Schlosser et al., 2015). The use of IT balanced scorecards including Green IT metrics to gauge financial and non-financial IT implications would improve organisational governance of IT (Ferguson et al. 2013). As opposed to scattered policies for Green IT implementation, an integrated and well-communicated Green IT policy would assist in better promoting a Green IT culture (Molla et al., 2011). Regular Green IT auditing would facilitate Green IT planning (Murugesan, 2008). Green IT monitoring and reporting would promote increasing stakeholder business trust (Harmon and Demirkan, 2011). IT Governance training (Nfuka and Rusu, 2011) including Green IT (Wabwoba et al., 2013) would also serve to promote the benefits of ITG practice and encourage its implementation.

The ITGM thus addresses the aim of this study to examine IT Governance and Green IT measures applied in large business from the five main pillars of the Mauritian economy. It's theoretical and practical relevance are discussed next.

\section{Theoretical and Practical Implications}

This study provides several contributions to both theory and practice. Firstly, the absence of conceptual models reconciling the governance of IT with Green IT in highly IT-dependent Small Island Developing States such as Mauritius is evident. Previous research appears to have shown some focus on developing countries (Wabwoba et al., 2013), but IT governance and Green IT remain uncharted both from a Mauritian and, overall SIDS' perspective. This paper provides an insight into the unexplored terrain of IT governance and Green IT in Mauritian businesses by presenting commonly used ITG and Green IT accountability modes, mechanisms and their drivers in the form of the ITGM. Secondly, the paper provides recommendations to both Mauritius and other similar SIDS with a high IT agenda for more effective ITG and Green IT implementation. Given the precarious environmental and economic situation of SIDS, it is envisaged that these recommendations will form the basis for improved ITG and Green IT both for increased business value and cleaner production. Thirdly, from a practitioner angle, the outcomes of this research not only assist businesses in optimising sustainable IT use; they also align with the strategic vision of the Mauritian government. As a Small Island Developing State, Mauritius faces numerous limitations in terms of its size, heavy dependency on international trade and extreme vulnerability to the dangers of climate change (UNDESA Division for Sustainable Development, 2014). Mauritius is conscious of its constraints, and is particularly wary of its susceptibility to global temperature rises and economic fluctuations. To build environmental resilience and secure a safe place on the world market, it is imperative that Mauritian strategies focus on the reinforcement of environmentally clean IT usage and 
reduction of carbon footprints. With IT superiority and environmental sustainability ranked high among the priorities of SIDS such as Mauritius, this study is of significant interest to Mauritian businesses, the Mauritian government and similar SIDS, as its resulting ITGM and recommendations provide a guide for businesses and government agencies to better harness the power of IT for improved business value and added sustainability drive.

\section{Conclusions}

This paper maps the unexplored IT Governance and Green IT landscape of the IT-dependent and environmentally susceptible SIDS of Mauritius onto the ITGM. Several drivers including the Mauritian legal environment, political vision and the need for business resilience and stakeholder satisfaction influence the adoption of ITG and Green IT practices in large, key companies of the island. The popularity of IT monarchies in the governance of IT and Green IT decisions reflects a need for strong executive control marked by centralised, enterprise-wide collaboration. Many ITG and Green IT mechanisms, including IT committees, strategic plans, risk management frameworks and Green IT awareness strategies, are commonly implemented for productive and sustainable IT use. Energy efficiency and clean e-waste disposal underlie existing Green IT leadership and policies. The ITGM also identifies popular measures promoting ecological IT use ('Greening IT'), business carbon footprint reduction through IT ('Greening by IT'), and environmentally-friendly technology. It also provides recommendations for improved ITG and Green IT. From a practical angle, therefore, the ITGM can guide organisations in optimising IT use for both business value and environmental responsibility. The model could assist Mauritius and other similar SIDS in enforcing industry resilience through technology, and collaborating with the government to achieve its vision of IT prominence and sustainability excellence.

One limitation of this study lies in the predominant participation of IT managers (58.7\%) as opposed to IT (19.8\%) and business executives (21.5\%). A second issue is the use of a 2007 database of companies which was the only one available at the time of this study. Future research should be based on a more current database of companies and could explore IT Governance and Green IT from wider views of both business and IT representatives at executive and lower management levels to build a more comprehensive and indepth model.

\section{Reference}

Akman, I., Mishra, A., 2015. Sector diversity in Green Information Technology practices: Technology Acceptance Model perspective. Comput. Human Behav. 49, 477-486. doi:10.1016/j.chb.2015.03.009

Ali, S., Green, P., Robb, A., 2013. Measuring Top Management's IT Governance Knowledge Absorptive Capacity. J. Inf. Syst. 27, 137-155. doi:10.2308/isys-50325

Anderson, J.C., Gerbing, D.W., 1988. Structural Equation Modeling in Practice: A Review and Recommended Two-Step Approach. Psychol. Bull. 103, 411-423. doi:10.1037/0033-2909.103.3.411

Ardito, L., Morisio, M., 2014. Green IT - Available data and guidelines for reducing energy consumption in IT systems. Sustain. Comput. Informatics Syst. 4, 24-32. doi:10.1016/j.suscom.2013.09.001

Bai, C., Kusi-Sarpong, S., Sarkis, J., 2017. An implementation path for green information technology systems in the Ghanaian mining industry. J. Clean. Prod. 164, 1105-1123. doi:10.1016/j.jclepro.2017.05.151

Bansal, P., Roth, K., 2000. Why Companies Go Green: a Model of Ecological Responsiveness. Acad. 
Manag. J. 43, 717-736. doi:10.2307/1556363

Baruch, Y., Holtom, B.C., 2008. Survey response rate levels and trends in organizational research. Hum. Relations 61, 1139-1160. doi:10.1177/0018726708094863

Bin-Abbas, H., Bakry, S.H., 2014. Assessment of IT governance in organizations: A simple integrated approach. Comput. Human Behav. 32, 261-267. doi:10.1016/j.chb.2013.12.019

Bohas, A., Poussing, N., 2016. An empirical exploration of the role of strategic and responsive corporate social responsibility in the adoption of different Green IT strategies. J. Clean. Prod. 1-12. doi:10.1016/j.jclepro.2016.02.029

Bose, R., Luo, X. (Robert), 2012. Green IT adoption: a process management approach. Int. J. Account. Inf. Manag. 20,63-77. doi:10.1108/18347641211201081

Bradley, R. V., Byrd, T.A., Pridmore, J.L., Thrasher, E., Pratt, R.M.E., Mbarika, V.W. a, 2012. An empirical examination of antecedents and consequences of IT governance in US hospitals. J. Inf. Technol. 27, 156-177. doi:10.1057/jit.2012.3

Budget Speech 2017-2018, 2017. . Minist. Financ. Econ. Dev. doi:10.1038/ncomms16127

Cai, S., Chen, X., Bose, I., 2013. Exploring the role of IT for environmental sustainability in China: An empirical analysis. Int. J. Prod. Econ. 146, 491-500. doi:10.1016/j.ijpe.2013.01.030

Chuang, S.P., Huang, S.J., 2014. Effects of Business Greening and Green IT Capital on Business Competitiveness. J. Bus. Ethics 128, 221-231. doi:10.1007/s10551-014-2094-y

Chugh, R., Wibowo, S., Grandhi, S., 2016. Environmentally sustainable Information and Communication Technology usage: Awareness and practices of Indian Information and Communication Technology professionals. J. Clean. Prod. 131, 435-446. doi:10.1016/j.jclepro.2016.05.004

Coltman, T., Tallon, P., Sharma, R., Queiroz, M., 2015. Strategic IT Alignment: Twenty-five Years on. J. Inf. Technol. 30, 91-100. doi:10.1057/jit.2014.35

De Haes, S., Van Grembergen, W., 2009. An Exploratory Study into IT Governance Implementations and its Impact on Business/IT Alignment. Inf. Syst. Manag. 26, 123-137. doi:10.1080/10580530902794786

De Haes, S., Van Grembergen, W., Debreceny, R.S., 2013. COBIT 5 and Enterprise Governance of Information Technology: Building Blocks and Research Opportunities. J. Inf. Syst. 27, 307-324. doi:10.2308/isys-50422

Debreceny, R.S., 2013. Research on IT Governance, Risk, and Value: Challenges and Opportunities. J. Inf. Syst. 27, 129-135. doi:10.2308/isys-10339

den Uyl, R.M., Driessen, P.P.J., 2015. Evaluating governance for sustainable development - Insights from experiences in the Dutch fen landscape. J. Environ. Manage. 163, 186-203. doi:10.1016/j.jenvman.2015.08.022

Dyer, N.G., Hanges, P.J., Hall, R.J., 2005. Applying multilevel confirmatory factor analysis techniques to the study of leadership. Leadersh. Q. 16, 149-167. doi:10.1016/j.leaqua.2004.09.009

El Idrissi, S.C., Corbett, J., 2016. Green IS research: A modernity perspective. Commun. Assoc. Inf. Syst. 38, 596-623.

Erek, K., Schmidt, N.-H., Zarnekow, R., Kolbe, L.M., 2009. Sustainability in Information Systems : Assortment of Current Practices in IS Organizations, in: Americas Conference on Information Systems (AMCIS) Proceedings. 
Ferguson, C., Green, P., Vaswani, R., Wu, G.H., 2013. Determinants of Effective Information Technology Governance. Int. J. Audit. 17, 75-99. doi:10.1111/j.1099-1123.2012.00458.x

Fujitsu, 2010. Green IT : The Global Benchmark. A report on sustainable IT in the USA, UK, Australia and India.

Gartner, 2018. Gartner Says Global IT Spending to Reach \$3.7 Trillion in 2018 [WWW Document]. URL https://www.gartner.com/newsroom/id/3845563

Gartner, 2007. Gartner estimates ICT industry accounts for $2 \%$ of global CO2 emissions. [WWW Document]. URL http://www.gartner.com/it/page.jsp?id=503867

Gefen, D., 2003. Assessing Unidimensionality Through LISREL : An Explanation and an Example. Commun. Assoc. Inf. Syst. 12, 23-47.

Government of Mauritius, 2015. Mauritius ready to submit its INDC in the context of COP21 [WWW Document]. URL http://www.govmu.org/English/News/Pages/Mauritius-ready-to-submit-its-INDCin-the-context-of-COP21.aspx

Harmon, R.R., Demirkan, H., 2011. The next wave of Sustainable IT. IT Prof. 13, 19-26.

Hu, L., Bentler, P.M., 1999. Cutoff criteria for fit indexes in covariance structure analysis: Conventional criteria versus new alternatives. Struct. Equ. Model. A Multidiscip. J. 6, 1-55. doi:10.1080/10705519909540118

Hu, L., Bentler, P.M., 1998. Fit indices in covariance structure modeling: Sensitivity to underparameterized model misspecification. Psychol. Methods 3, 424-453. doi:10.1037/1082989X.3.4.424

ITGI, 2011. Global Status Report on the Governance of Enterprise It ( GElt ) - 2011, Governance An International Journal Of Policy And Administration.

Jairak, K., Praneetpolgrang, P., Subsermsri, P., 2015. Information technology governance practices based on sufficient economy philosophy in the Thai university sector. Inf. Technol. People 28, 195-223.

Jenkin, T. a., Webster, J., McShane, L., 2011. An agenda for "Green" information technology and systems research. Inf. Organ. 21, 17-40. doi:10.1016/j.infoandorg.2010.09.003

Kalumiya, N., Kannan, A.P., 2015. Mauritius 2015 [WWW Document]. African Econ. Outlook. URL http://www.africaneconomicoutlook.org/fileadmin/uploads/aeo/2015/CN_data/CN_Long_EN/Ma uritius_GB_2015.pdf

Melville, N.P., 2010. Information Systems Innovation for Environmental Sustainability. MIS Q. 34, 1-21.

Ministry of Environment and Sustainable Development, 2013. Maurice lle Durable Policy, Strategy and Action Plan [WWW Document].

Ministry of Information and Communication Technology, 2013. National Green IT Strategy, Policy and Action Plan.

Mishra, D., Akman, I., Mishra, A., 2014. Theory of Reasoned Action application for Green Information Technology acceptance. Comput. Human Behav. 36, 29-40. doi:10.1016/j.chb.2014.03.030

Molla, A., Abareshi, A., 2012. Organizational Green Motivations for Information Technology: Empirical Study. J. Comput. Inf. Syst. 52, 92-102.

Molla, A., Abareshi, A., 2011. Green IT Adoption : A Motivational Perspective, in: Pacific Asia Conference on Information Systems (PASIS) Proceedings.

Molla, A., Abareshi, A., Cooper, V., 2014. Green IT beliefs and pro-environmental IT practices among IT 
professionals. Inf. Technol. People 27, 129-154. doi:10.1108/ITP-10-2012-0109

Molla, A., Cooper, V., 2009. Green IT Readiness : A Framework and Preliminary Proof of Concept. J. Inf. Syst. 16, 5-23.

Molla, A., Cooper, V., Pittayachawan, S., 2011. The Green IT Readiness ( G-Readiness ) of Organizations : An Exploratory Analysis of a Construct and Instrument. Commun. Assoc. Inf. Syst. 29, 67-96.

Mulaik, S. a., James, L.R., Van Alstine, J., Bennett, N., Lind, S., Stilwell, C.D., 1989. Evaluation of goodness-of-fit indices for structural equation models. Psychol. Bull. 105, 430-445. doi:10.1037/0033-2909.105.3.430

Murugesan, S., 2008. Harnessing Green IT: Principles and Practices. IT Prof. 10, 24-33. doi:10.1109/MITP.2008.10

Nfuka, E.N., Rusu, L., 2011. The effect of critical success factors on IT governance performance. Ind. Manag. Data Syst. 111, 1418-1448. doi:10.1108/02635571111182773

Roses, L.K., Brito, J.C.B., Lucena, G.J. De, 2015. Conversational competences model for information technology and business strategic alignment. J. Inf. Syst. Technol. Manag. 12, 125-144. doi:10.4301/S1807-17752015000100007

Rubino, M., Vitolla, F., 2014. Corporate governance and the information system: how a framework for IT governance supports ERM. Corp. Gov. Int. J. Bus. Soc. 14, 320-338. doi:10.1108/CG-06-2013-0067

Schlosser, F., Beimborn, D., Weitzel, T., Wagner, H.-T., 2015. Achieving social alignment between business and IT - an empirical evaluation of the efficacy of IT governance mechanisms. J. Inf. Technol. 30, 119-135. doi:10.1057/jit.2015.2

Segars, A.H., Grover, V., 1993. Re-Examining Perceived Ease of Use and Usefulness : A Confirmatory Factor Analysis. MIS Q. 17, 517-525.

Sohal, A.S., Fitzpatrick, P., 2002. IT governance and management in large Australian organisations. Int. J. Prod. Econ. 75, 97-112.

Sourcemauritius.com, 2015. Vision 2030 : Key focus areas [WWW Document]. URL http://sourcemauritius.com/wp-content/uploads/2015/09/Brief_vision-2030.pdf

Statistics Mauritius, 2015. Environment Statistics - 2014 [WWW Document]. URL http://statsmauritius.govmu.org/English/StatsbySubj/Pages/Environment-Statistics-Year2014.aspx

Straub, D., Boudreau, M.-C., Gefen, D., 2004. Validation Guidelines for IS Positivist Research. Commun. Assoc. Inf. Syst. 13, 380-427.

The Ministry of Environment and Sustainable Development, 2011. Maurice Ile Durable Green Paper Towards a National Policy for a Sustainable Mauritius [WWW Document]. URL www.gov.mu/portal/goc/menv/files/gp-main2011.pd

The World Bank, 2015. Mauritius - Systematic Country Diagnostic.

Uddin, M., Rahman, A.A., 2012. Energy efficiency and low carbon enabler green IT framework for data centers considering green metrics. Renew. Sustain. Energy Rev. 16, 4078-4094. doi:10.1016/j.rser.2012.03.014

UNDESA Division for Sustainable Development, 2014. Partnerships Briefs for Small Island Developing States - Sustainable Economic Development.

United Nations Sustainable Development Knowledge Platform, 2017. Small Island Developing States 
[WWW Document]. URL https://sustainabledevelopment.un.org/topics/sids/list

Vykoukal, J., Wolf, M., Beck, R., 2009. Does Green IT Matter ? Analysis of the Relationship between Green IT and Grid Technology from a Resource-Based View Perspective, in: Pacific Asia Conference on Information Systems (PASIS) Proceedings.

Wabwoba, F., Omuterema, S., Wanyembi, G., Omieno, K., 2013. Green ICT Readiness Model for Developing Economies: Case of Kenya. Int. J. Adv. Comput. Sci. Appl. 4, 51-65.

Wang, N., Chang, Y.-C., 2014. The development of policy instruments in supporting low-carbon governance in China. Renew. Sustain. Energy Rev. 35, 126-135. doi:10.1016/j.rser.2014.03.021

Watson, R.T., Boudreau, M.-C., Chen, A.J., 2010. Information Systems and Environmentally Sustainable Development : Energy Informatics and New Directions for the IS Community. MIS Q. 34, 23-38.

Weill, P., 2004. Don ' t Just Lead , Govern : How Top-Performing Firms Govern IT. MIS Q. 8.

Willson, P., Pollard, C., 2009. Exploring IT Governance in Theory and Practice in a Large Multi-National Organisation in Australia. Inf. Syst. Manag. 26, 98-109. doi:10.1080/10580530902794760

World Risk Report Analysis and Prospects [WWW Document], 2017. URL https://reliefweb.int/sites/reliefweb.int/files/resources/WRR_2017_E2.pdf

Xia, D., Chen, B., Zheng, Z., 2014. Relationships among circumstance pressure, green technology selection and firm performance. J. Clean. Prod. 106, 487-496. doi:10.1016/j.jclepro.2014.11.081 